\title{
Semmelweis Ignác kései tanszékvezetői utódjának megemlékezése
}

\author{
Papp Zoltán dr. \\ Maternity Szülészeti és Nőgyógyászati Magánklinika, Budapest
}

\begin{abstract}
1990 és 2007 között Semmelweis Ignác nyolcadik tanszékvezetői utódjaként a Baross utcai Női Klinikán döntően a nagy felfedezéshez szükséges feltételek szerencsés összetalálkozása, reménytelen küzdelmei, halálának körülményei, négyszeri kihantolása és ötszöri temetése, névmagyarosítása és a vele kapcsolatos tudatos vagy véletlen tévedések foglalkoztattak. Megemlékezésemben a nagy elődre vonatkozó élményeimet és tapasztalataimat foglalom össze. Orv Hetil. 2018; 159(26): 1071-1078.
\end{abstract}

Kulcsszavak: Semmelweis Ignác, gyermekágyi láz, asepsis, kézmosás

\section{Recollection of the great predecessor by a late successor leader}

\begin{abstract}
Between 1990 and 2007, being the eighth successor leader following Ignác Semmelweis at the university department of obstetrics in Baross Street, what interested me mainly were the following: the lucky coincidences needed for the great discovery, the doctor's hopeless struggles, the circumstances of his death, his five burials and fourfold exhumations, the Hungarianization of his name and the deliberate or unintentional mistakes related to him. In the recollection, my impressions and experiences related to the great predecessor will be reviewed.
\end{abstract}

Keywords: Ignác Semmelweis, puerperal fever, asepsis, handwashing

Papp Z. [Recollection of the great predecessor by a late successor leader.] Orv Hetil. 2018; 159(26): 1071-1078.

(Beérkezett: 2018. április 15.; elfogadva: 2018. április 30.)

Semmelweis Ignác születésének 200. évfordulója évében a Szerkesztőség felkérésére készített tanulmány.

Semmelweis Ignác nyolcadik tanszékvezetői utódjaként sokat olvastam a nagy előd életéról és haláláról, korszakalkotó felfedezéséről és annak fogadtatásáról; igyekeztem 1990 és 2007 között ápolni emlékét, és próbáltam a magam számára feloldani azt a sok ellentmondó adatot, amely a vele foglalkozó, egész könyvtárat megtöltő orvostörténelmi munkákban található. Döntően a nagy felfedezéshez szükséges feltételek szerencsés összetalálkozása, reménytelen küzdelmei, halálának körülményei, négyszeri kihantolása és ötszöri temetése, névmagyarosítása és a vele kapcsolatos tudatos vagy véletlen tévedések foglalkoztattak.

Nagy szerepe volt a tévhitek terjesztésében a szakirodalmi igényességet nélkülöző munkák sokaságának és a róla megjelent kritikátlan sajtóhíreknek, valamint a magyar játékfilmeknek is. (Egyébként külföldön is készülttek róla filmek, a Fred Zinnemann által 1938-ban rendezett rövidfilm [That mothers might live - Hogy élhessenek az anyák] Oscar-díjat kapott.) A magyar játékfilmekről Benedek István professzor tömören azt írta, hogy „egyik rosszabb, mint a másik" [1]. A filmek történelmi hitelessége sok kívánnivalót hagy maga után, mindegyik az akkori korszellem hú lenyomata. Benedek Istvánnak van egyébként a legnagyobb érdeme abban, hogy megszabadította a nagy orvost az évtizedek során rárakódott romantikus máztól és nacionalista elfogultságtól [2, 3].

A Semmelweis életével foglalkozó irodalmat végigkíséri egyfajta álszemérem, amellyel a „nagy” embereket általában megfosztják valódi egyéniségüktől. 2014-ben Katona Zsuzsa rendezett dokumentumfilmet „Életmentő - Semmelweis Ignác igaz története" címmel, mely szintén nem mentes a romantikus és prúd elemektől. A halálát például kizárólag a vérbajra vezeti vissza, amelyet Semmelweis mütét során egy betegétől kapott, és figyel- 
men kívül hagyja a kórboncolással is igazolt generalizált sepsist mint közvetlen halálokot. Merész dolog egyedüli üdvözítő verziónak bemutatni a filmet, valószínúleg még a ma élő orvosok közül sem vállalkozhatna senki arra, hogy Semmelweis „igaz történetét” megírja. Nekem szülészként és kései utódjaként is csak az adatik meg, hogy egyes vitás orvostörténeti kérdésekben állást foglalva, a személyes klinikai vonatkozásokat és az általam fontosnak tartott szerény gondolataimat összegyújtsem, és születésének 200. évfordulóján papírra vessem. Munkám során felhasználtam a professzori pályafutásom során Semmelweis Ignácról írt munkáimat és a róla tartott beszédeimet, előadásaimat [4-12].

\section{A gyermekágyi láz rövid története}

A „gyermekágyi láz” nagy valószínűség szerint olyan régi, mint maga a szülés. A szakmai köztudatba a XVII. század végén és a XVIII. században lépett be. Először François Mauriceau (1637-1709) francia szülész (férfi bába?) írta le a tüneteket, majd Thomas Willis (16211675 ) használta először a ,febris puerperarum” kifejezést. Edward Strother 1716-ban írt először a „puerperal fever”-röl („tejláz, amely a szülés utáni 3. napon jelentkezik, valószinüleg a lochia okozta gyulladás következtében”). A XVIII. század végén a kórházakban fekvő gyermekágyasok betegségének kezdték tartani, és a XIX. század elején járványos halmozódások során néhány \%-os volt a kórházakban a halálozás [13, 14].

$\mathrm{Az}$ orvostörténeti visszaemlékezések közül kiemelkedik a Londonban 1769-ben lejegyzett, a kórházban bentfekvő gyermekágyasok között magas lázzal és hashártyagyulladással járó megbetegedések halmozódása, majd Aberdeenben (Skócia) 1789. december és 1792. január között figyeltek meg gyermekágyiláz-járványt. Ez utóbbi részletesen lejegyzett adataival a briliáns epidemiológus, Alexander Gordon (1752-1799) foglalkozott behatóan és igényesen. 1795-ben egyedülálló beszámolót közölt az aberdeeni járványról, amelyben megállapította, hogy (a) a betegség contagiosus, egyik személyről (orvosról, szülésznőről, szülőnőról) terjed a másikra, (b) a betegség és az erysipelas között közvetlen kapcsolat van, és hogy (c) a venasectio az egyedüli terápiás esély. Húsz évvel korábban Charles White (1728-1813) Manchesterből arról írt, hogy a fertőzést okozó putridus anyag a bélből juthat a méhbe, és nem a szülőcsatornából, ugyanakkor hangsúlyozta a tiszta levegő és a tisztaság fontosságát a megelőzésben [13].

\section{Zsoldos János magyar szülészorvos intelmei 1814-ből}

Lehet, hogy tudott róla Semmelweis Ignác, lehet, hogy nem, de tény, hogy Zsoldos János (1767-1832), Veszprém vármegye „Első rendes orvosa” 1814-ben Semmelweis Ignác tanítása előtt 33 évvel „Diaetetika” című,
Győrben kiadott könyvében félreérthetetlenül leszögezi, hogy szülés után és előtt a bábának lúgos, majd szappanos vízzel meg kell mosnia a kezét, ,sebes kézzel valamely rothadt vagy maradványsebbez ne nyúljon, magát és eszközeit megmossa”. Több kiadást megért, de magyar nyelven írt munkáját, sőt versbe szedett szabályait a „,bemosakodás" fontosságáról a református iskolákban tanították, de ez nem jutott el magasabb helyekre. Zsoldos János egyébként a napóleoni háború idején több ezer francia és osztrák sebesültet kezelt Pápa kórházaiban az antiszeptikus hatású szerek (kámfor, „égetett szesz”) alkalmazásával és az asepsis szabályainak betartásával. Érdekesség, hogy Lister, az antisepsis hivatalosan elismert hirdetője és apostola még 1885-ben is szalonkabátban és kézmosás nélkül végezte mútéteit, mivel kizárólag a levegő fertőtlenítését tartotta fontosnak. Egyébként Zsoldos János volt a pápai „Asszony Ispotályi Intézet” alapítója [15].

\section{Az első hazai egyetemi szülészeti tanszék Semmelweis Ignác előtt}

A bécsi és számos más egyetem után az 1811/1812. tanévtól királyi hozzájárulással hivatalosan Pesten is önállóvá vált az elméleti és gyakorlati szülészeti („ars obstetriciae theoretica-practica”) tanszék [16]. Élére a király 1812. április 7-én Frankenburg Jakab (1781-1814) sebész- és orvosdoktor szülészmestert nevezte ki, aki rövid múködése során igyekezett az elhanyagolt állapotokon segíteni és az oktatást megszervezni, de Pest város tanácsa és a kórház igazgatója elzárkózott minden kezdeményezése elól. Csalódottan halt meg 1814-ben. A megüresedett tanszékre kiírt pályázaton hárman indultak, de az orvosi kar nem találta óket alkalmasnak, így 1814-tól három évig Stábly Ignác, a bonctan tanára oktatta megbízottként a szülészetet. 1816. december 16-tól lett ismét (négy évtizeden át) önálló vezetője a tanszéknek Birly Ede Flórián (1787-1854) személyében. Birly dr. szakirodalmi tevékenysége nem ismeretes, inkább a gyakorlatias szülészkedés mesterének tartották, a kíméletes várakozást követve szövődmények esetén. A gyermekágyi láz okát a belek tisztátlanságában látta, és hashajtókat rendelt a betegeknek, közben a klinikát a gyermekágyi láz nagy aránya miatt többször be kellett zárni. Klinikai pályafutásának utolsó éveiben családi és társasági kapcsolatban állt az idóközben Bécsból hazatért Semmelweis Ignáccal, azonban nem vett tudomást eredményeiről. (Semmelweis egyébként 1851-tôl lett a Rókus Kórház Szülészeti Osztályának vezetője mint fizetés nélküli főorvos, és a kötelező kézmosás bevezetésével nagy örömére az osztályán $1 \%$ alá szorította az anyai halálozást.)

\section{Semmelweis felfedezésének születése}

Mi az oka annak, hogy mégsem Zsoldos Jánosnak, hanem Semmelweis Ignácnak tulajdonítja a világ az asepsis jelentőségét a szülészetben? Semmelweis annyival volt 
több, hogy feltételezését tudományosan bizonyítani tudta. Sokszor volt már a tudomány történetében, hogy a tapasztalatokra épülő gyakorlat akkor vált elfogadottá, ha a feltételezés tudományosan bizonyíthatóvá vált.

Semmelweisnek szülészeti pályafutása során szembesülnie kellett a gyermekágyi láz rettenetes kórképével, tehetetlenül együtt éreznie az anyákkal, továbbá szenvedélyes és elszánt elhivatottságra, kitartásra és szorgalomra volt szüksége az ok megtalálásához.

Ezenkívül szükséges volt a felfedezéséhez a bécsi kórbonctani irányzat (Semmelweis a tanulmányai befejezése után Rokitansky patológiai intézetében dolgozott, és ott sajátította el azt a „kórbonctani elvet”, hogy a betegségek kórokát a boncasztalnál is ellenórizni kell, illetve lehet megtalálni) és az eltérő oktatási elveket valló két bécsi szülészeti klinika is. A kizáráson alapuló diagnosztikai módszer, az éles klinikai megfigyelőképesség és a statisztikai anyag bizonyító erejének felhasználása kétségtelenül Bécsben vált a fiatal klinikus kutató Semmelweis orvosi gondolkodásmódjának és tudományos módszerének részévé. Kutatásának gondolatfelvetése a betegágynál indult, és a megoldás is oda vezetett vissza. Ehhez a veleszületett tehetségére és képességeire, továbbá a magyar általános és középiskolai tanulmányai során szerzett felkészültségére is szülkség volt. „A szerencse csak azokat látogatja meg, akik felkészülten várják.” Tehát nemcsak a kórbonctan bécsi virágzása, a nagy betegforgalmú bécsi klinikák összehasonlításra alkalmas nagy kórtörténeti anyaga, hanem Semmelweis személyiségjegyei is kellettek a felfedezéshez és annak bizonyításához. Meghatározó volt boldog és szerető légkörü gyermekkora, édesapja biztató és bőkezű támogatása tanulmányaihoz, szorgalmas diákévei, számos kiváló magyarországi tanára [17]. Semmelweis Ignác felfedezése tehát nem a véletlen múve volt.

Az 1847 tavaszán megfogalmazott felfedezése akkor vált számára is meggyőzővé, amikor Jakob Kolletschka professzor, az Igazságügyi Orvostani Intézet tanára a boncasztalnál szerzett sérülését követően két héten belül, 1847. március 13-án vérmérgezésben meghalt. Semmelweis izgatottan olvasta a férfiholttest boncolási jegyzőkönyvét, melyben gyakorlatilag a gyermekágyi lázban meghalt nők patológiai leírását tapasztalhatta.

Semmelweis Ignác felfedezése nemcsak a „bécsi iskola" eredménye volt, hiszen Semmelweis távozását követően nem akadt senki a bécsi egyetemen, hogy Semmelweis kutatásait folytassa, illetve hogy azt egyáltalán értékelje.

Ugyanígy a Kolletschka professzor bonclelete és a gyermekágyi lázban elhunyt édesanyák kórbonctani képe közötti hasonlóságot, sőt azonosságot senki nem ismerte fel Bécsben, még Rokitansky professzor sem, és így kizárólag Semmelweis vonta le a következtetést, tehát a felfedezés Semmelweis Ignác kizárólagos eredménye volt.

Említésre méltó, hogy Bécsben 1789-től álltak rendelkezésre a szülészeti kórlapok. Az általam 1990 és 2007 között vezetett Baross utcai Női Klinikán az 1874-től
Kézmárszky Tivadarnak köszönhetően megőrzött kórlapokat beköttettük, és tárolásukról gondoskodtunk. Az adatvédelmi biztos 1995 és 2005 közötti többszöri kezdeményezése (és feljelentése) ellenére nem semmisítettük meg 30 évtől visszamenóleg a kórlapokat, hanem azokat egy szerződésben a Semmelweis Orvostörténeti Múzeumnak ajándékoztuk, a múzeum pedig tárolási nehézségeire hivatkozással megkérte a Klinikánkat, hogy tároljuk a dokumentumokat [11]. Ha ilyen adatvédelmi törvény a XIX. században, Bécsben létezett volna, akkor Semmelweis sem tehette volna meg statisztikai adatokra épített felfedezését (1.ábra).

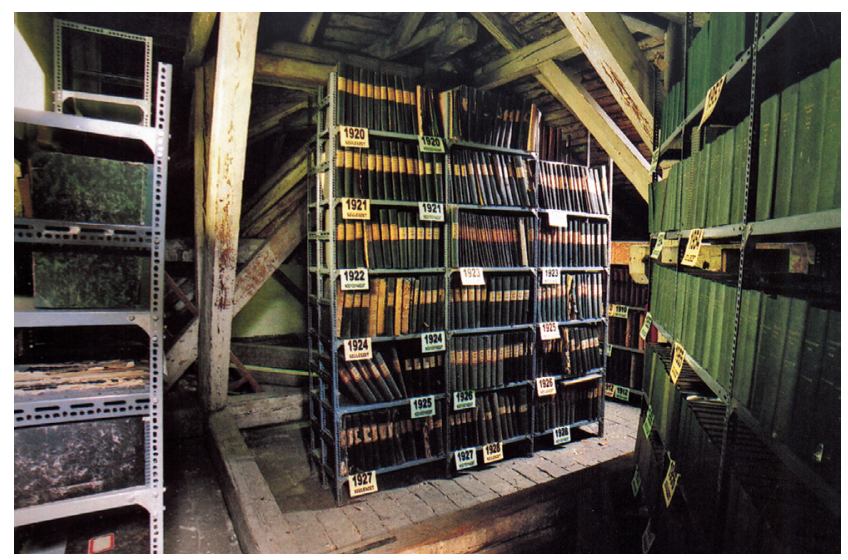

1. ábra

A Klinika padlásterében 1991-ben kialakított kórlaparchívum ban (1874-tól bekötött állapotban) Salgó polcrendszeren tároltuk a mind tudományos, mind orvostörténeti szempontból jelentős klinikai dokumentumokat

Semmelweis „nem ragadott tollat, hogy közzétegye megfigyeléseit”[18-21]. Két évig nem mert kiállni. Hallgatása elbizonytalanította környezetét. Semmelweis Bécsben megbukott. Skoda professzor kiállt mellette, de ő nem a gyermekágyas anyák érdekeit nézte, hanem az egyetem autonómiáját féltette. Ennek egyik fegyvere volt a magyar orvos. Rokitansky hamarosan rektor lett, Skoda az egyetem legnagyobb tekintélye, mégsem hívták vissza, hogy rehabilitálják. Mindketten hatalmuk teljében voltak, de 1856-ban, amikor Klein professzor meghalt, a sebész Dumreicher magánindítványát mégsem karolták fel, jóllehet aláírták; jobbnak látták, ha Semmelweis Ignác nem jön vissza Bécsbe, és az egyre elmérgesedő nemzetközi vitában egyikük sem hallatta egyszer sem a szavát, a bécsi egyetem többi tanárához hasonlóan.

\section{Semmelweis Ignác utódjai}

Ha iskolateremtő magyar szülészorvost kell megneveznünk, akkor elsőként a pesti szülészeti tanszék élére 1855-ben kinevezett Semmelweis Ignác (1818-1865) jut eszünkbe. Jóllehet klasszikus értelemben nem hozott létre „iskolát”, halála után évtizedekkel mi, magyarországi szülészek őt tekinthetjük példaképünknek. Kortárs tanítványai közül Fleischer József (1829-1877) és Maizner János (1828-1902) neve érdemel kizárólag kieme- 
lést, akik közül az előbbit a Rókus Kórház Szülészeti Osztályára nevezték ki főorvosnak, az utóbbi pedig Kolozsvárott lett az egyetem szülészeti és nőgyógyászati tanszékének első tanára. Semmelweis Ignác halála után mindketten szóba jöttek utódként, azonban a tanszéket Balassa János sebészprofesszor támogatásával az alkalmatlannak bizonyult Diescher János (1813-1883) kapta [16].

A Klinikán a szülészeti szakmai munka színvonala Diescher dr. múködése alatt nagymértékben romlott. Nem tette magáévá Semmelweis elméletét a gyermekágyi lázról, és nem követte a megelőzést célzó utasításait sem. Miután a Klinikán megszaporodott (6\%-osra emelkedett!) gyermekágyi lázas eseteket megfékeznie nem sikerült, a tanári kar kezdeményezésére 1873-ban maga kérte nyugdíjazását. Semmelweis 1847. évi korszakalkotó felfedezését hazájában sem tanszéki elődje, sem utódja nem fogadta el $[5,6]$ !

Semmelweis tanársegédje és kezdetben hű követője, Fleischer József még Semmelweisnek ajánlotta 1857-ben írt bábakönyvének első kiadását, de az 1869. évi kiadásban, Semmelweis halála után 4(!) évvel már nem szerepel az ajánlás, és utalás sincs a könyvben arra, hogy az ő elveit követi. Ebben az időben a Klinikán már nem illett említeni Semmelweis nevét. Ambró Jánosnak (18271889), a pozsonyi bábaképző intézet igazgató tanárának köszönhető, hogy Semmelweis neve és tanai egyelőre nem mentek teljesen feledésbe: az 1873-ban szlovák nyelven is kiadott népszerü bábakönyvét Semmelweisnek ajánlotta, és Pozsonyban a bábákat az ő szellemében nevelte.

Első éveiben Diescher János utódja, Kézmárszky Tivadar (1842-1902) sem kötötte Semmelweis nevéhez az asepsis fogalmát, később azonban méltó utódnak bizonyult (1874-től haláláig vezette a Klinikát). Elévülhetetlen érdemeket szerzett a Baross utcai Klinika épületének megtervezésében és „beüzemelésében”.

Az épület fennállásának 100. évfordulóját a Klinikán országos rendezvény keretében 1996-ban megünnepeltük, ennek kapcsán egy magyar és egy angol nyelvü kötetet adtunk ki [5, 6]. Egyébként 1990 és 2002 között önerőből, nem állami és nem egyetemi keretből, hanem alapítványainknak köszönhetően az épületet felújítottuk, belső átépítéseket végeztünk, és igényes helyet kapott többek között a Genetikai Laboratórium és Tanácsadás, az Ultrahang-Laboratórium, az Asszisztált Reprodukciós Osztály (ARO), a Fetopatológiai Laboratórium, a Neonatalis Intenzív Centrum (NIC) és az új mútőblokk [22].

1903 és 1926 között Bársony János (1860-1926), majd két évig Kubinyi Pál (1870-1928), 1929 és 1948 között Frigyesi József (1875-1967), majd 24 évig Horn Béla (1902-1983), 1972 és 1990 között pedig Csömör Sándor (1919-2007) volt a Klinika igazgatója.

Semmelweis Ignác nyolcadik tanszékvezetői utódjának 1990. július 1-jén engem neveztek ki, aki 17 éven át, 2007. június 30-ig vezettem a Klinikát. Mint kései utód, sokat foglalkoztam Semmelweis Ignác életével és munkásságával is, de igyekeztem a többi előd emlékét is ápolni, többek között azzal, hogy Semmelweis Ignác szarkofágján kívül munkatársaimmal felkerestük és megkoszorúztuk 2004. szeptember 25-én a Fiumei úti sírkertben Birly Ede Flórián, Diescher János és Frigyesi József sírját is. Mivel Bársony János sírkövét összetörve találtuk, helyére új síremléket csináltattunk. Horn Béla sírját a Farkasréti temetőben koszorúztuk meg [23]. Kézmárszky Tivadar sírját halálának 101. évfordulóján, Lőcsén, klinikai munkatársi kirándulás keretében 2003. május 17-én kerestük fel [24] (2. és 3. ábra).

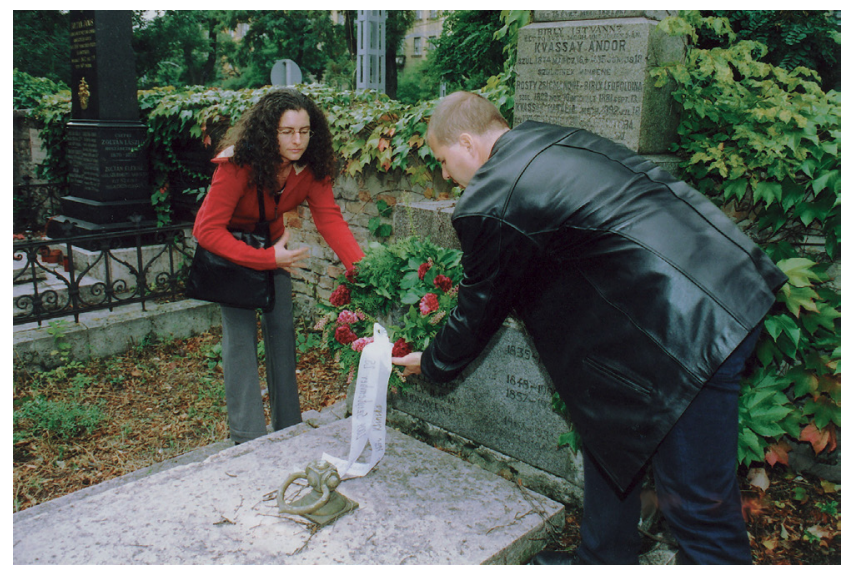

2. ábra $\mid$ Munkatársaim 2004. szeptember 25-én megkoszorúzzák Birly Ede Flórián síremlékét a Fiumei úti sírkertben

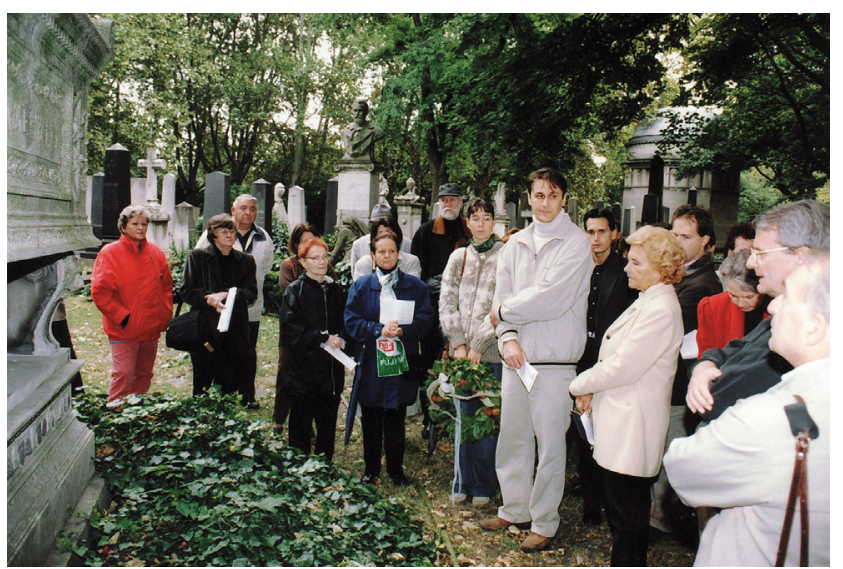

3. ábra

A Klinika munkatársai Semmelweis Ignác szarkofágjánál, a Fiumei úti sírkertben (2004. szeptember 25.)

Kubinyi Pál sírját egy miskolci utam során a régi temetőben 2004. november 28-án koszorúztam meg, így végül kizárólag Frankenburg Jakab nyughelyét nem sikerült kiderítenem. 2007. március 26-án gyászbeszéddel búcsúztattam közvetlen elődömet, Csömör Sándor professzort [25].

Semmelweis mellett az iskolateremtő magyar szülészek másik nagy alakja Tauffer Vilmos (1851-1934). Ö már klasszikus értelemben is valódi iskolateremtőnek tekinthető. Nevéhez kapcsolható a korszerü operatív nő- 
gyógyászat kifejlesztése hazánkban. Jelentős szerep jutott neki a szerencsétlen sorsú Semmelweis Ignác, nagy magyar elődje érdemeinek sajnálatosan megkésett hazai és nemzetközi elismertetésében. Ismert tevékeny közremúködése Hegar professzor monográfiájának megszületésében, aki már az 1870-es években elfogadta Semmelweis tanítását. Tauffer Vilmos a tagja, majd az elnöke volt a Kézmárszky Tivadar kezdeményezésére 1891-ben megalakult emlékbizottságnak, amely Semmelweis Ignác tiszteletére szobor és díszes síremlék felállítását határozta el. 1906. szeptember 30-án nemzetközi ünnepség keretében Tauffer Vilmos nagy hatású beszédével leplezték le az Erzsébet téren Stróbl Alajos alkotását, és Tauffer professzor javaslatára nevezték el Semmelweisről a pesti Újvilág utcát, ahol az egyetemi klinika korábban állt [26].

Paulin Ferenc professzorral, a II. Női Klinika igazgatójával 2000-ben úgy határoztunk, hogy a magyar szülészet-nőgyógyászat két legnagyobb alakja, Semmelweis Ignác és Tauffer Vilmos, a két pesti klinika korábbi igazgatója és emblematikus orvosa tiszteletére kétévente Semmelweis-Tauffer Emlékülést rendezünk, melyeken a visszaemlékezések mellett egy-egy ma élő kiemelkedő magyar szülészorvos egyéniségnek Emlékdíjat adunk át. Az első tudományos fórumot Tauffer Vilmos születésének 150. évfordulóján, 2001. október 10-én tartottuk. Az első két díjazott Zoltán Imre és Csömör Sándor, tanszéki elődeink voltak. Ekkor mutatta be Gazda István az általa szerkesztett „Semmelweis Ignác emlékezete” címü kétkötetes könyvet [27]. Még két alkalommal rendeztünk Semmelweis-Tauffer Emlékülést, Emlékdíjat adományoztunk többek között Iffy László, Jankó Béla és Zsolnai Béla professzoroknak. Nyugdíjaztatásom után a hagyomány nem folytatódott [28] (4. ábra).

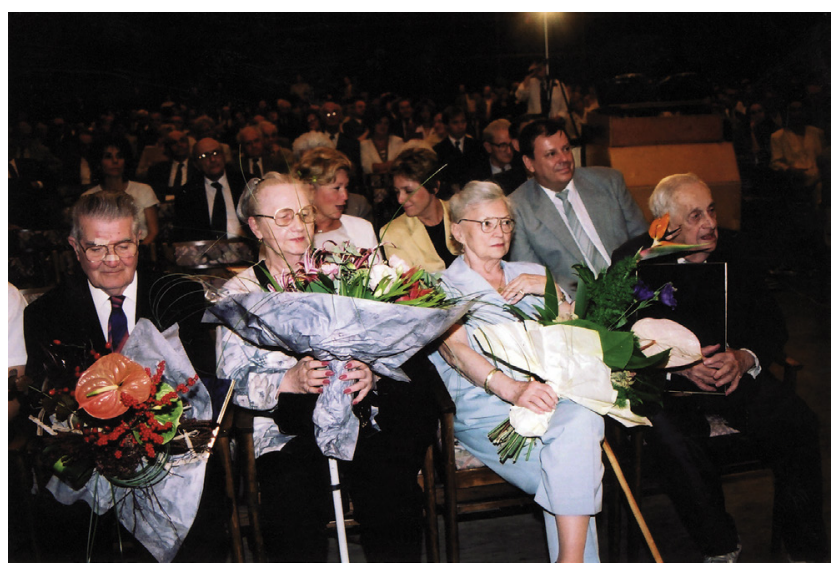

4. ábra

Az ünnepelt Csömör Sándor és Zoltán Imre professzorok feleségükkel az első Semmelweis-Tauffer Emlékülésen (2001. október 10.)

Semmelweis Ignác nem egyszerűen egy hazai iskolát, hanem a világ szülészeti osztályainak szemléletét befolyásoló korszakváltást hozott létre. De ahhoz meg kellett halnia, hogy az utókor erre rájöjjön. A késóbbiekben külföldön, fóleg a német szülészek, fel- és elismerték
Semmelweis felfedezésének jelentőségét. A régi ellenfelek is engedtek tiltakozásukból, Joseph Späth, August Hirsch, Gustav Veit, Franz Winckel, Carl Gustav Braun, Wilhelm F. Scanzoni, Otto Spiegelberger és Karl Schoeder is elismerte, hogy a gyermekágyi láz okának felfedése Semmelweis érdeme. A teljes áttörést azonban az irodalomban Alfred Hegar (1830-1914) freiburgi szülészprofesszor Semmelweisről 1882-ben írt könyve jelentette.

Semmelweis híre Japánba is eljutott: ennek egy kedves bizonyítéka az a levél, amelyet a posta kissé megkésve, 2005. március 10-én hozott „Professor Ignaz Philipp Semmelweis 1085 Budapest, Üllöi út 26. Hungary, Europe” címre. A levelet a címzett „utólagos” engedélyével én bontottam fel, amelyben gratuláltak Semmelweis doktornak a kézmosással elért eredményeihez, és mellékeltek egy képes útmutatót, hogy intézetükben milyen elóírások szerint mosnak kezet [11].

Az asepsis fontosságának gondolatát azóta folyamatosan ébren tartani a nagy nemzetközi „Semmelweis-iskola” minden tagjának kötelessége. Iffy Lászlónak, az 1956-os forradalom után külföldre kényszerült, a 2016ban bekövetkezett haláláig mindvégig elkötelezett magyarságú szülészprofesszornak kiemelkedő szerepe volt abban, hogy Semmelweis munkásságának aktualitása bekerült az amerikai köztudatba. Mint klinikai igazgató, az asepsis szigorú bevezetésével látványosan javította a New Jersey Egyetem Szülészeti Klinikáján a perinatalis eredményeket a XX. század második felében [29].

\section{Semmelweis halála és négyszeri kihantolása}

A Klinika igazgatásának utolsó éveiben küzdelmei megviselték Semmelweis professzor szervezetét, lelkiállapotát; idegrendszeri tünetek léptek fel, viselkedése eltorzult, furcsa szokásokat vett fel. Annak a bizonyos bábaeskünek a felolvasása a kinevezések értékelése helyett az orvosi karban az utolsó csepp volt a pohárban. (Több orvostörténész nem fogadja el ennek megtörténtét, mivel a legújabb kutatások szerint ezt először dr. Fleischer József Semmelweis halála után hét évvel írta, ugyanakkor bizonyítható módon személyesen nem is volt jelen a szóban forgó ülésen.) Pár nappal később a Kar felkérésére a gyermekgyógyász Bókay János megvizsgálta Semmelweis Ignácot, és szervi eltérés nélkül mentálisan betegnek nyilvánította. Nem tudni, hogy milyen alapos lehetett a vizsgálat, mivel a leletben nincs utalás a jobb kéz középső ujjának akkor már nyilvánvaló és valószínúleg sebészi ellátást igénylő gangraenájára. Az állítólagos bábaeskü felolvasása után 8 nappal, 1865. július 30-án az éjszakai vonattal felesége és néhány orvoskollégája kíséretében Bécsbe utazott, ahol régi barátja, Hebra professzor várta. Az előre letáviratozott akció szerint Hebra azt ígérte neki, hogy az új szanatóriumába viszi. Mint felesége 1905-ben nyilatkozta, férje a bécsi pályaudvaron nagyon megörült barátjának, és követte öt az intézetbe, hogy megtekintse azt [30]. 
1865. július 31-én betoloncolták az Alsó-ausztriai Elmegyógyintézetbe. Már első nap dühöngeni kezdett, hat ápoló alig bírt vele. Menekülni próbált, de összeverték, kényszerzubbonyba zárták, elsötétített szobában ágyhoz kötözték, feleségének nem engedték, hogy férjét meglátogassa [18-21]. Alig két héten belül, 1865. augusztus 13-án generalizált sepsisben meghalt. (A kórházi felvétel idején mutatott általános fizikális állapota nem magyarázta, hogy két héten belül paralysis progressivában kellett volna meghalnia.) A gyermekágyi láz okának felfedezője a Lazarettgassén lévő elmegyógyintézetben durva erőszak, szennyes környezet és felelőtlen ellátás áldozata lett. Ezt erősítette meg a Rokitansky professzor irányításával történt kórbonctani leírás is: a pyaemia a jobb középső ujjának gangraenájából indulhatott ki, és áttétet adott a bal kéz mutatóujjának kézközépcsontjába, a vesékbe; testszerte számos mélyre hatoló gennyes áttétje, a bal mellkasban perforáló tályogja volt [18-21, 31].

Egy kései adat szerint Machik Béla, aki később Kolozsvárott a belgyógyászat tanára lett, 1865-ben a Landesirrenanstaltban múködött segédorvosként, és jelen volt Semmelweis kórházi felvételénél; a későbbiekben többször nyilatkozott tanítványainak, hogy Semmelweis nem magával hozott sebfertőzésbe, hanem a brutális bánásmód okozta sérülésekbe halt bele, de amikor a hír 1906ban szárnyra kapott, már nem erősíthette ezt meg, mert 27 éve halott volt $[2,5]$.

Boncolás után Semmelweis tetemét 1865. augusztus 16-án a schmelzi sírkertben temették el.

Első kihantolására a temető felszámolása miatt 1891. április 15-én került sor, földi maradványait a Kerepesi úti temetőben két nappal később a Walthier családi sírboltban helyezték el [30]. A harmadik temetésére 1894. április 21-én került sor, hogy a maradványokat díszsírba tegyék. 1929. november 23-án újra kihantolták, és maradványait és a márvány síremléket a mészkő szarkofággal együtt a „múvész-író” parcellába helyezték át. Sikerült a Fiumei úti sírkert nyilvántartásában a három temetés bejegyzéseit megtalálnunk és lefényképeznünk [32] (5. ábra).

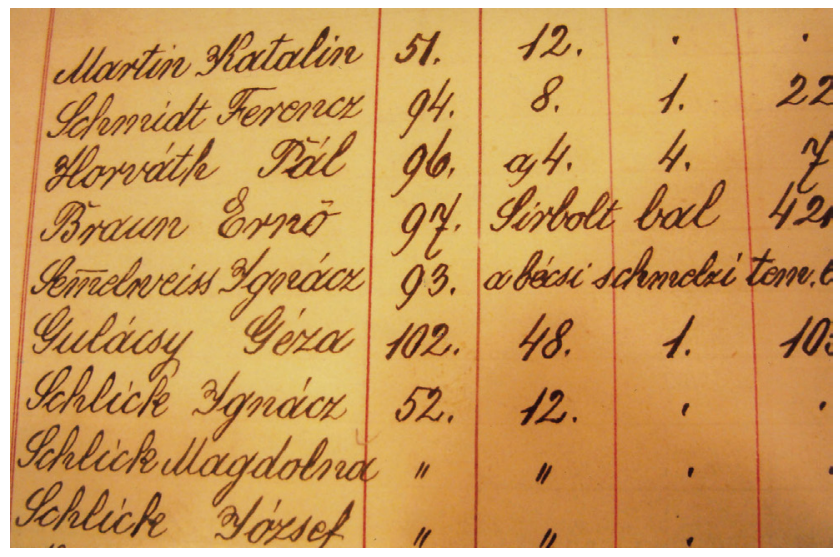

5. ábra

Részlet a Fiumei úti sírkert 1891. évi nyilvántartásából. „Semelweiss Ignácz" neve mellett szerepel, hogy a bécsi schmelzi temetôből helyezték át

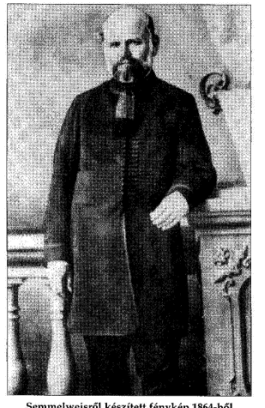

Dr. Papp Zoltán:

Emlékbeszéd

Semmelweis Ignác

Fülöp emléktáblájánál

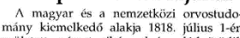

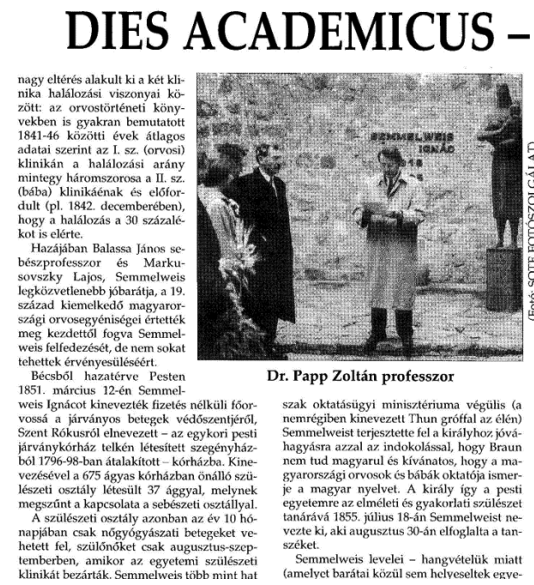

6. ábra

A szerző emlékbeszédét tartja Semmelweis Ignác szülőházának kertjében Semmelweis halálának 130. évében, 1995. november 6-án, a Dies Academicus Egyetemi Nap programjában (Semmelweis Egyetem, 1995. november 22.; 2-3. old.)

Negyedik alkalommal 1963. november 6-án ásták elő maradványait, melyeket Bartucz Lajos professzor, az egyetem Embertani Intézetének igazgatója azonosított. Semmelweis Ignác halálának közelgő 100. évfordulója tiszteletére, 1964. október 15-én csontjait a Semmelweis Orvostörténeti Múzeumba, szülőháza kertjébe, remélhetőleg már végső nyughelyére helyezték [32-36].

Évek óta hagyomány, hogy a Semmelweis Egyetem tanárai és diákjai minden évben a Dies Academicus ünnepségsorozat keretében megkoszorúzzák a tabáni szülőház kertjében felállított emlékfalat, és egy megemlékezés hangzik el [4] (6. ábra).

A Semmelweis Ignácról elnevezett akkori alapítványunknak köszönhetően 2002-ben a Baross utcai Női Klinika udvarán felavattunk egy márványoszlopon álló bronzszobrot, amelyet születésnapján, minden július elsején ünnepség keretében megkoszorúztunk. A mellszobor Veres Gábor alkotása, szerintem a legsikerültebb és számomra a legkedvesebb szobor Semmelweisről [37] (7. és 8. ábra).

\section{Semmelweis Ignác magyarsága és névváltoztatása}

Egyes nemzetek a lexikonjaikban még ma is osztráknak tartják a nagy magyar orvost. Ezzel szemben Semmelweis Ignác német hangzású neve ellenére mindig magyarnak vallotta magát. Budán született, az általános és középiskolai (a várbeli és a Piarista Gimnázium) nyilvántartásban „hungarus”-ként szerepelt. Magyarságát bizonyítja az is, hogy utódaira magyar nevet kívánt hagyni, ezért nevét 1849-ben Szemerényire változtatta. Ebben valószínúleg szerepet játszott, hogy az 1848/49-es forradalom és szabadságharc idején „a nemzeti felszabadulás aspirációiban" erősen lábra kapott a névmagyarosítás. Vezetéknevének Szemerényire történt változtatását egyébként az akkori hivatalos „Közlöny” az 1849. május 


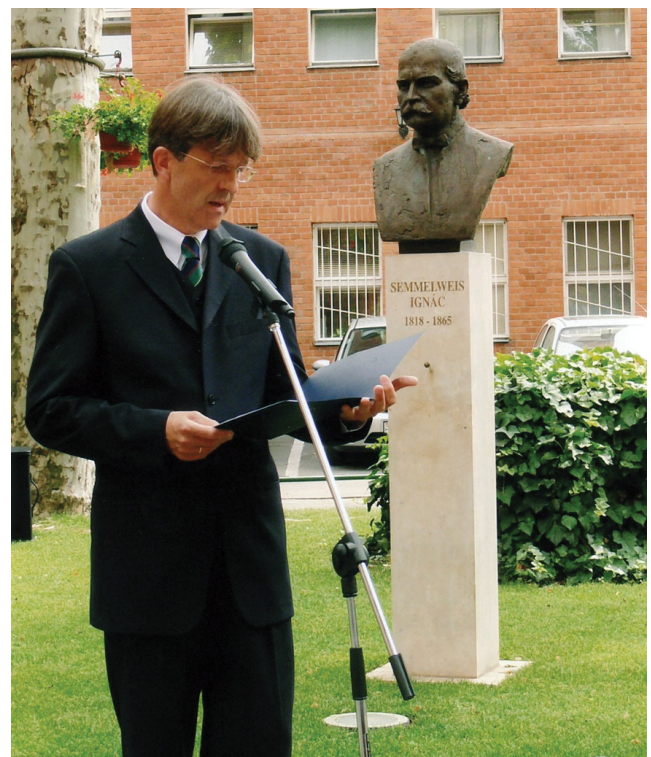

7. ábra

Kedves tanítványom, Urbancsek János professzor Semmelweismegemlékezését tartja a Klinika kertjében Semmelweis Ignác szobra előtt 2006. július elsején (Semmelweis Egyetem, 7. évf. 8. szám, 2006. szeptember 19.)

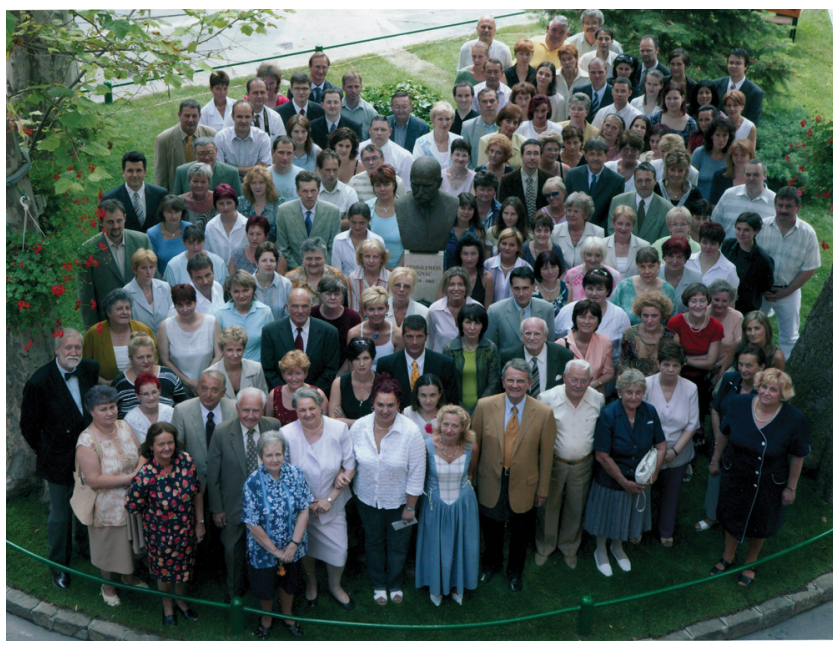

8. ábra

A Baross utcai Szülészeti Klinika munkatársai Semmelweis Ignác szobra körül 2005-ben

13-i számában hozta nyilvánosságra [38]. Néhány hónappal késóbb, a szabadságharc leverése után a bécsi kormány szigorúan megtiltotta a magyarosított nevek használatát, $s$ mindenki köteles volt eredeti nevét visszavenni. Csak 1867-ben indulhatott meg újból a névváltoztatási mozgalom. Weidenhofer Mária, Semmelweis Ignác felesége a férje halála után ismét folyamodott az 1849-es határozat megerôsítéséért, és a Szemerényi nevet a belügyminisztérium végül engedélyezte az özvegy és a gyerekek számára. Egyébként a család több tagja is magyarosította a nevét, többek között Ignác bátyja, Szemerényi Károly, aki Ignác és Mária esküvőjén az esketést végző lelkész volt. Természetesen számunkra a nagy magyar orvos neve mindig Semmelweis Ignác marad.

\section{Zárógondolat}

A semmelweisi asepsisszabályok betartása ellenére napjainkban is létezik erysipelas, skarlát, nekrotizáló fascitis, cellulitis, acut glomerulonephritis, intrauterin és újszülöttkori pneumonia, valamint gyermekágyi láz, melyekért az A csoportú Streptococcus okozta fertózés a felelős. A Streptococcus azonban már nem a „régi”. Az antibiotikumok széles körú alkalmazása valószínúleg molekuláris változásokat idézett elő a baktériumokban. A gyógyszeres kezeléseknek és a korszerû sebészi beavatkozásoknak köszönhetôen halálesetek ma már ritkán fordulnak elő. Az asepsis elveinek betartása mindennél fontosabb. Ezt szolgálja például a mai szülészeti gyakorlatban a várandós nók hüvelyváladékából végzett tenyésztés a B csoportú Streptococcus (GBS) kimutatására. Pozitív tenyésztési eredmény esetén antibiotikumprofilaxist alkalmazunk $[39,40]$.

Anyagi támogatás: A közlemény megírása anyagi támogatásban nem részesült.

A szerző a cikk végleges változatát elolvasta és jóváhagyta.

Érdekeltségek: A szerzőnek nincsenek érdekeltségei.

\section{Irodalom}

[1] Benedek I. Why are so many false data circulating about Semmelweis? [Miért kering oly sok téves adat Semmelweisről?] Orv Hetil. 1968; 109: 1551-1554. [Hungarian]

[2] Benedek I. Semmelweis and his age. [Semmelweis és kora.] Gondolat Kiadó, Budapest, 1967. [Hungarian]

[3] Benedek I. Ignaz Philipp Semmelweis (1818-1865). Hermann Böhlaus Nachf. Ges. M.B.H., Wien-Köln-Graz, 1983. [German]

[4] Papp Z. Memorial speech at the plaque of Ignác Fülöp Semmelweis. [Emlékbeszéd Semmelweis Ignác Fülöp emléktáblájánál.] Semmelweis Egyetem 1995. november 22.; 2-3. old. [Hungarian]

[5] Papp Z. (ed.) The past and present of the clinic of Ignác Semmelweis. Centennial Memorial Book on the 100th anniversary of the construction of the Obstetric and Gynaecological Clinic in Baross street. [Semmelweis Ignác klinikájának múltja és jelene. Jubileumi Emlékkönyv a Baross utcai Szülészeti és Nőgyógyászati Klinika építésének 100. évfordulóján.] Golden Book Kiadó, Budapest, 1996. [Hungarian]

[6] Papp Z. (ed.) Past and present of the First Department of Obstetrics and Gynaecology of Semmelweis University Medical School. The volume in honour of the centennial of the Baross Street building in Budapest. Golden Book Kiadó, Budapest, 1996.

[7] Papp Z. Commemorative speech at closing ceremony of the academic year on Semmelweis Day, on 1st July 1999. [Tanévzáró ünnepi beszéd a Semmelweis-napon, 1999. július elsején.] Semmelweis Egyetem 1999. szeptember 16.; 3-4. old. [Hungarian]

[8] Papp Z. What has changed and what has not since Semmelweis? Commemoration lecture at the donation of "Ignác Semmelweis Commemorative Medal and Prize" award on 30th September 1999. [Mi változott, és mi nem Semmelweis óta? Emlékelőadás a „Semmelweis Ignác Emlékérem és Jutalomdij” átvételekor 1999. szeptember 30-án.] MOTESZ Magazin 2000; 1-2: 47-56. [Hungarian] 
[9] Papp Z. Foreword. In: Gazda I. (ed.) Memory of Ignác Semmelweis I-II. [Előszó. In: Gazda I. (szerk.) Semmelweis Ignác emlékezete I-II.] Semmelweis Orvostörténeti Múzeum, Könyvtár és Levéltár, Budapest-Piliscsaba, 2001; pp. 9-17. [Hungarian]

[10] Papp Z. Semmelweis Memorial Speech. [Semmelweis Emlékbeszéd.] Semmelweis Egyetem 2007. szeptember 21.; 7-8. old. [Hungarian]

[11] Papp Z. On the traces of Ignác Semmelweis and Tivadar Kézmárszky. [Semmelweis Ignác és Kézmárszky Tivadar nyomdokain.] White Golden Book Kiadó, Budapest, 2008. [Hungarian]

[12] Papp Z. The pioneers of gynaecological medicine: Ignác Semmelweis, Vilmos Tauffer. History repeats itself. [A nőorvoslás úttörői: Semmelweis Ignác, Tauffer Vilmos. A történelem ismétli önmagát.] Medical Tribune 2008. december 18.; 4. old. [Hungarian]

[13] Loudon I. The tragedy of childbed fever. Oxford University Press, Oxford-New York, 2000.

[14] Nuland SB. The doctors' plague. Germs, childbed fever, and the strange story of Ignác Semmelweis. W. W. Norton \& Company, New York-London, 2003.

[15] Csillag I. New data to the Hungarian background of the Semmelweis concept. [Újabb adatok a Semmelweis-koncepció magyarországi elôzményéhez.] Orvostört Közl. 1970; 55-56: 201206. [Hungarian]

[16] Kápolnai I. The independent faculty of obstetrics until the appointment of Semmelweis. In: Gazda I. (ed.) The memory of Ignác Semmelweis I-II. [Az önálló szülészeti tanszék Semmelweis kinevezéséig. In: Gazda I. (szerk.) Semmelweis Ignác emlékezete I-II.] Semmelweis Orvostörténeti Múzeum, Könyvtár és Levéltár, Budapest-Piliscsaba, 2001; pp. 178-183. [Hungarian]

[17] Antall J. The role of family and school in the formation of the personality of Semmelweis. [A család és az iskola szerepe Semmelweis személyiségének kialakulásában.] Orvostört Közl. 1968; 46-47: 95-126. [Hungarian]

[18] Silló-Seidl G. Die letzte Stätte von Semmelweis und sein echtes Sektionsprotokoll. [Semmelweis utolsó tartózkodási helye és kórboncolásának autentikus leírása.] Comm Hist Artis Med. (Budapest) 1976; 22: 61-82. [Article in German]

[19] Silló-Seidl G. Neue Daten zu den letzten zwei Wochen vor Semmelweis' Tod. [Új adatok Semmelweis életének utolsó két hetéről.] Comm Hist Artis Med. (Budapest) 1976; 22: 111-116. [Article in German]

[20] Silló-Seidl Gy. The medical record of Semmelweis in the Lower Austria Mental Asylum. [Semmelweis kórtörténete az Alsó-ausztriai Elmegyógyintézetben.] Orv Hetil. 1977; 118: 859-862. [Hungarian]

[21] Silló-Seidl Gy. The death of Semmelweis. Medical history report. [Semmelweis halála. Orvostörténelmi beszámoló.] Metropolitan Verlag, Münchenstein, 1977. [Hungarian]

[22] Papp Z, Csabay L. The renovated building of the Department of Obstetrics and Gynecology in the Baross Street. [A megújult Baross utcai Nói Klinika.] Semmelweis Ignác Alapítvány, Budapest, 2002. [Hungarian]

[23] Páger M. Pilgrimage to history. [Zarándokút a történelembe.] Semmelweis Egyetem 2005. március 11. [Hungarian]

[24] Páger M. Laying of wreath at the grave of Tivadar Kézmárszky in Lő́cse. [Kézmárszky Tivadar sírjának megkoszorúzása Lőcsén.] Semmelweis Egyetem 4. évf. 8. szám (2003. június 16.) [Hungarian]
[25] Papp Z. Commemoration of death of Sándor Csömör (19192007). [Megemlékezés Csömör Sándor (1919-2007) haláláról.] Nőgyógy Szül Továbbk Szle. 2007; 9: 94-95.; Orv Hetil. 2007; 148: 1041-1042.; Magy Nőorv L. 2007; 70: 191.; Semmelweis Egyetem 8/8: 2007. június 18. [Hungarian]

[26] Papp Z. Vilmos Tauffer. In: Gazda I. (ed.) The memory of Ignác Semmelweis I-II. [Tauffer Vilmos. In: Gazda I. (szerk.) Semmelweis Ignác emlékezete I-II.] Semmelweis Orvostörténeti Múzeum, Könyvtár és Levéltár, Budapest-Piliscsaba, 2001; pp. 479-485. [Hungarian]

[27] Gazda I. (ed.) The memory of Ignác Semmelweis I-II. [Semmelweis Ignác emlékezete I-II.] Semmelweis Orvostörténeti Múzeum, Könyvtár és Levéltár, Budapest-Piliscsaba, 2001. [Hungarian]

[28] Donáth T. Cherishing the memory of our great ones. [Ápoljuk nagyjaink emlékét.] Semmelweis Egyetem 2/12: 2001. október 26. [Hungarian]

[29] Iffy L. A Hungarian physician in the large world. [Magyar orvos a nagyvilágban.] Semmelweis Kiadó, Budapest, 2012. [Hungarian]

[30] Widow of Semmelweis about his husband. [Semmelweis özvegye a férjéról.] Budapesti Hirlap 1906. október 2.; 8. old. [Hungarian]

[31] Scheuthauer TR, Meynert TM. An examination of the corpse of Semmelweis. [Semmelweis holt testének vizsgálata.] Orv Hetil. 1865; 6: 763-768. [Hungarian]

[32] Papp Z. The exhumation of Ignác Semmelweis on four occasions. [Semmelweis Ignác négyszeri kihantolása.] Semmelweis Egyetem VI/5, 16. old. 2005. április 15. [Hungarian]

[33] Bartucz L. The four exhumations of Semmelweis. [Semmelweis négyszeri exhumálása.] Természet Világa 1965; 546-550. old. [Hungarian]

[34] Gortvay Gy, Zoltán I. Semmelweis. His life and work. Akadémiai Kiadó, Budapest, 1968.

[35] Gortvay Gy, Zoltán I. Semmelweis, Retter der Mütter. [Semmelweis, az anyák megmentője.] S. Hirzel Verlag, Leipzig, 1976. [German]

[36] Céline L-F. Semmelweis. Pesti Kalligram Kft. Kiadó, BudapestPozsony, 2012. [Hungarian]

[37] Donáth T. New Ignác Semmelweis bronze statue in the courtyard of Gynaecological Department No 1. [Új Semmelweis Ignác bronzszobor az I. Női Klinika udvarán.] Semmelweis Egyetem, III/18. szám, 2002. szeptember. [Hungarian]

[38] Darvas I. The changing of names by Semmelweis. [Semmelweis névmagyarosítása.] Orv L. 1947; 2188. [Hungarian]

[39] Papp Z. Textbook of obstetrics and gynecology. 5th edn. [A szülészet-nőgyógyászat tankönyve. Ötödik kiadás.] Semmelweis Kiadó, Budapest, 2017. [Hungarian]

[40] Sziller I, Szabó M, Valek A, et al. The situation of prevention of early neonatal type B Streptococcus sepsis in Hungary in 2012. [A korai kezdetű újszülöttkori B csoportú Streptococcus-szepszis megelőzésének helyzete Magyarországon 2012-ben.] Orv Hetil. 2014; 155: 1167-1172. [Hungarian]

Papp Zoltán dr.,

Budapest, Kútvölgyi út 4., 1125 e-mail: pzorvosihetilap@maternity.hu

Megjegyzés: A fényképeket dr. Csabay László munkatársam készítette 